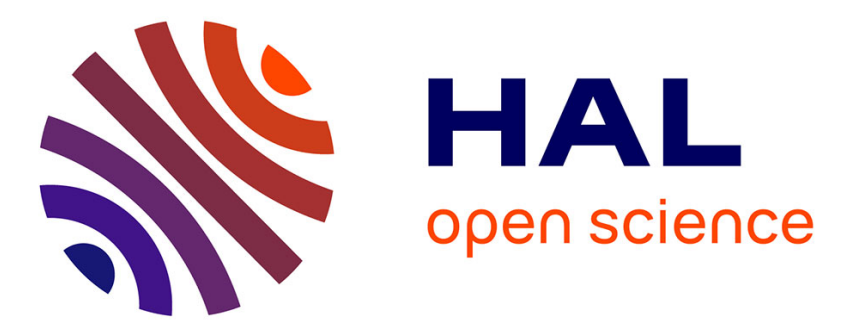

\title{
Nitrification amplifies the decreasing trends of atmospheric oxygen and implies a larger land carbon uptake
}

P. Ciais, A. Manning, M. Reichstein, S. Zaehle, L. Bopp

\section{- To cite this version:}

P. Ciais, A. Manning, M. Reichstein, S. Zaehle, L. Bopp. Nitrification amplifies the decreasing trends of atmospheric oxygen and implies a larger land carbon uptake. Global Biogeochemical Cycles, 2007, 21 (2), pp.GB 2030. 10.1029/2006GB002799 . hal-02924926

\section{HAL Id: hal-02924926 \\ https://hal.science/hal-02924926}

Submitted on 31 Aug 2020

HAL is a multi-disciplinary open access archive for the deposit and dissemination of scientific research documents, whether they are published or not. The documents may come from teaching and research institutions in France or abroad, or from public or private research centers.
L'archive ouverte pluridisciplinaire HAL, est destinée au dépôt et à la diffusion de documents scientifiques de niveau recherche, publiés ou non, émanant des établissements d'enseignement et de recherche français ou étrangers, des laboratoires publics ou privés. 


\title{
Nitrification amplifies the decreasing trends of atmospheric oxygen and implies a larger land carbon uptake
}

\author{
P. Ciais, ${ }^{1}$ A. C. Manning, ${ }^{2}$ M. Reichstein, ${ }^{3}$ S. Zaehle, ${ }^{1}$ and L. Bopp ${ }^{1}$ \\ Received 22 July 2006; revised 21 January 2007; accepted 23 February 2007; published 28 June 2007.
}

[1] Atmospheric $\mathrm{O}_{2}$ trend measurements are used to partition global oceanic and land biotic carbon sinks on a multiannual basis. The underlying principle is that a terrestrial uptake or release of $\mathrm{CO}_{2}$ is accompanied by an opposite flux of $\mathrm{O}_{2}$. The molar ratio of the $\mathrm{CO}_{2}$ and $\mathrm{O}_{2}$ terrestrial fluxes should be 1 , if no other elements are considered.

However, reactive nitrogen produced by human activities (e.g., fertilizers, $\mathrm{N}$ deposition) is also being incorporated into plant tissues. The various reaction pathways of the terrestrial nitrogen cycle cause fluxes of atmospheric $\mathrm{O}_{2}$. Thus the cycles of nitrogen, carbon, and oxygen must be linked together. We report here on previously unconsidered anthropogenic nitrogen-related mechanisms which impact atmospheric $\mathrm{O}_{2}$ trends and thus the derived global carbon sinks. In particular, we speculate that anthropogenic-driven changes are driving the global nitrogen cycle to a more oxidized state, primarily through nitrification, nitrate fertilizer industrial production, and combustion of fossil fuels and anthropogenic biomass burning. The sum of these nitrogen-related processes acts to additionally decrease atmospheric $\mathrm{O}_{2}$ and slightly increase atmospheric $\mathrm{CO}_{2}$. We have calculated that the effective land biotic $\mathrm{O}_{2}: \mathrm{CO}_{2}$ molar ratio ranges between 0.76 and 1.04 rather than 1.10 (moles of $\mathrm{O}_{2}$ produced per mole of $\mathrm{CO}_{2}$ consumed) over the period 1993-2003, depending on which of four contrasting nitrogen oxidation and reduction pathway scenarios is used. Using the scenario in which we have most confidence, this implies a $0.23 \mathrm{PgC} \mathrm{yr}^{-1}$ correction to the global land biotic and oceanic carbon sinks of most recently reported estimates over 1993-2003, with the land biotic sink becoming larger and the oceanic sink smaller. We have attributed large uncertainties of $100 \%$ to all

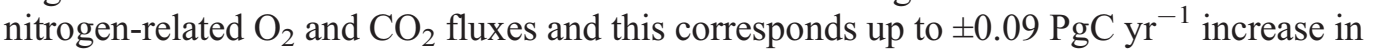
global carbon sink uncertainties. Thus accounting for anthropogenic nitrogen-related terrestrial fluxes of $\mathrm{O}_{2}$ results in a $45 \%$ larger land biotic sink of $0.74 \pm 0.78 \mathrm{PgC} \mathrm{yr}^{-1}$ and a slightly smaller oceanic sink of $2.01 \pm 0.66 \mathrm{PgC} \mathrm{yr}^{-1}$ for the decade 1993-2003.

Citation: Ciais, P., A. C. Manning, M. Reichstein, S. Zaehle, and L. Bopp (2007), Nitrification amplifies the decreasing trends of atmospheric oxygen and implies a larger land carbon uptake, Global Biogeochem. Cycles, 21, GB2030, doi:10.1029/2006GB002799.

\section{Introduction}

[2] High-precision measurements of atmospheric oxygen trends are used to partition the uptake of anthropogenic $\mathrm{CO}_{2}$ between land and oceans [see, e.g., Keeling and Shertz, 1992]. The quantification of the global carbon budget by the Third Assessment Report of the Intergovernmental Panel on Climate Change [Prentice et al., 2001] rests upon atmospheric oxygen measurements. The underlying principle is that the dissolution of anthropogenic $\mathrm{CO}_{2}$ into the ocean has no $\mathrm{O}_{2}$ counterflux, whereas the uptake of $\mathrm{CO}_{2}$ by terrestrial plants is mirrored by an opposing $\mathrm{O}_{2}$ flux. The $\mathrm{O}_{2}$ to $\mathrm{CO}_{2}$

\footnotetext{
${ }^{1}$ Laboratoire des Sciences du Climat et de l'Environnement, Gif-surYvette, France.

${ }^{2}$ School of Environmental Sciences, University of East Anglia, Norwich, $\mathrm{UK}$

${ }^{3}$ Max-Planck Institute for Biogeochemistry, Jena, Germany.

Copyright 2007 by the American Geophysical Union. 0886-6236/07/2006GB002799
}

ratio in land biotic fluxes commonly used in carbon sink calculations is $1.10 \pm 0.05$ moles of $\mathrm{O}_{2}$ produced per mole of $\mathrm{CO}_{2}$ consumed [Severinghaus, 1995; Manning and Keeling, 2006]. Photosynthesis emits $\mathrm{O}_{2}$ to the atmosphere and respiration is usually assumed to absorb atmospheric $\mathrm{O}_{2}$ following this same ratio. Thus the mass of oxygen in the terrestrial biosphere decreases over time if photosynthesis exceeds respiration. However, determining the precise value of this ratio is problematic [Manning and Keeling, 2006; Seibt et al., 2004], particularly for respiration, which could have large variations over temporal scales and ecosystem ranges [Randerson et al., 2006]. Recent studies have suggested molar ratios between 1.0 and 1.1 [Manning, 2001; Marca, 2004; Seibt et al., 2004; Stephens et al., 2007], however these studies have not been very comprehensive.

[3] Although there is no oceanic $\mathrm{O}_{2}$ counter-flux directly as a result of fossil fuel $\mathrm{CO}_{2}$ emissions, there is an indirect effect caused by the fact that the global oceans have warmed [Levitus et al., 2000]. The ocean warming signal, combined with changes in ocean dynamics and biology, has likely 


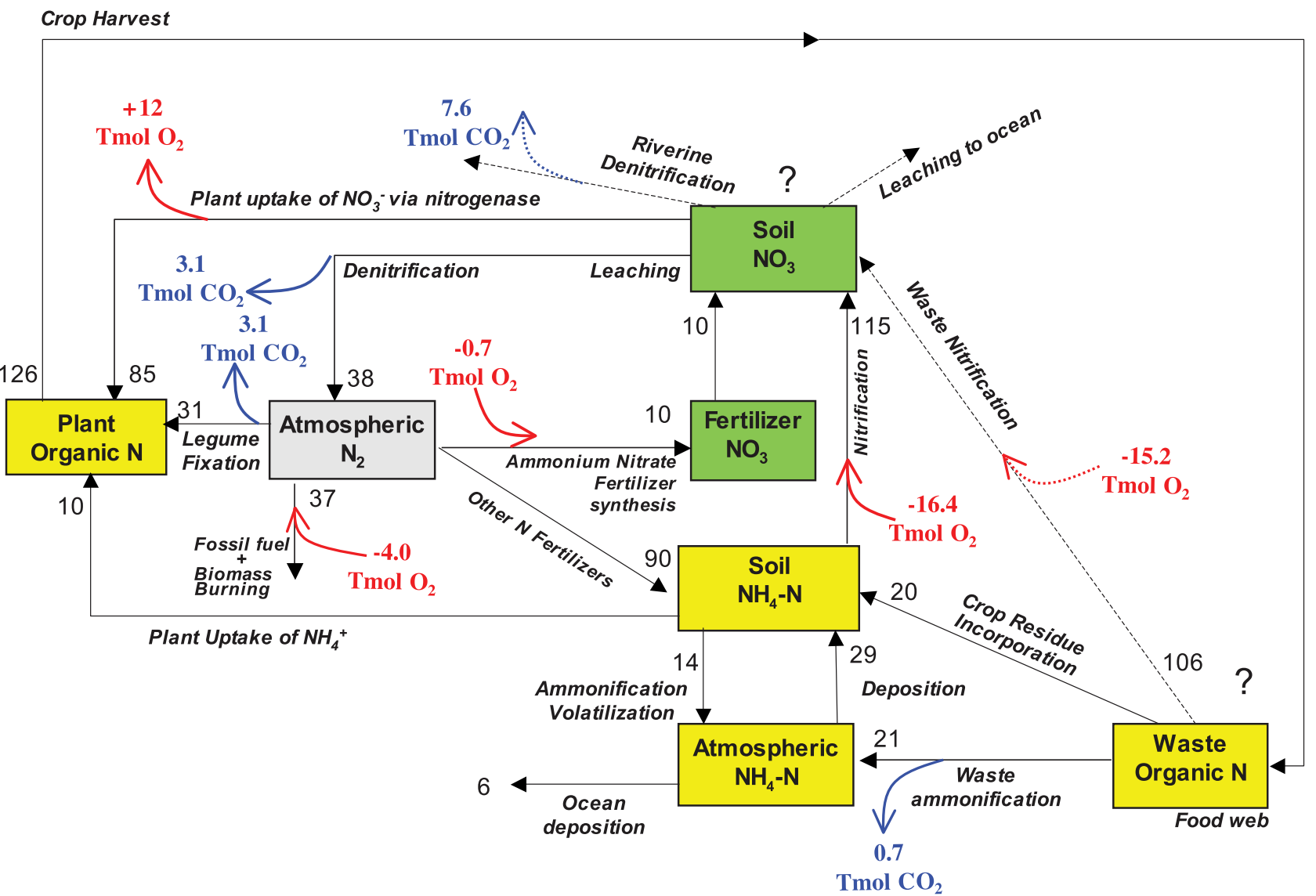

Figure 1. Component fluxes of the anthropogenic perturbation of the global nitrogen cycle fluxes (all fluxes are changes between present day and pre-industrial). Denitrification of groundwater or soil nitrate ions into $\mathrm{N}_{2} \mathrm{O}$ rather than into $\mathrm{N}_{2}$ is a small flux, not shown in the figure (see text). In red are the nitrification oxidizing reactions causing net uptake of $\mathrm{O}_{2}$ from the atmosphere (see Table 1). In blue are the denitrification reactions causing a release of $\mathrm{CO}_{2}$ to the atmosphere. In black are all other perturbation fluxes of nitrogen that are neutral with respect to $\mathrm{O}_{2}$ and $\mathrm{CO}_{2}$. Nitrogen perturbation fluxes are expressed in $\mathrm{TgN} \mathrm{yr}^{-1}$, and where applicable, the associated fluxes of $\mathrm{O}_{2}$ or $\mathrm{CO}_{2}$ are expressed in $\mathrm{Tmol} \mathrm{yr}^{-1}$.

affected the air-sea $\mathrm{O}_{2}$ flux over the last decades (for a review, see work by Bender et al. [2005]). This effect has been taken into account to correct $\mathrm{O}_{2}$-derived global carbon budgets by introducing an oceanic $\mathrm{O}_{2}$ outgassing flux derived from observed air-sea heat fluxes [Bopp et al., 2002; Keeling and Garcia, 2002; Plattner et al., 2002]. The corresponding ocean outgassing correction amounts to

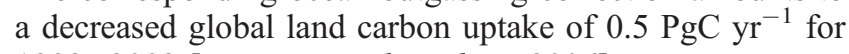
1993-2003 [Manning and Keeling, 2006].

[4] Here we report on mechanisms which alter the $\mathrm{O}_{2}$ to $\mathrm{CO}_{2}$ ratio of the terrestrial fluxes in response to anthropogenic activities. These mechanisms create a net sink of $\mathrm{O}_{2}$ from the atmosphere, with less significant counterbalancing $\mathrm{CO}_{2}$ emissions. They are a side consequence of the humandriven oxidation of the reactive nitrogen cycle (Figure 1). The mechanisms analyzed here imply a revision to the oxygen method to derive the global carbon budget.

\section{Background}

[5] Nitrogen fertilizer use has risen sharply over the past century. The mobilization of reactive $\mathrm{N}$ in fertilizers is thought to contribute to increased emission of nitrogen oxides and $\mathrm{NH}_{4}-\mathrm{N}$ by soils, and thus to increased deposition from the atmosphere [Frink et al., 1999]. Also, the combustion of liquid fossil fuels [Marland et al., 2003] and biomass burning [Mouillot et al., 2006] has increased dramatically over the second half of the past century, contributing to increased nitrogen oxides emissions. These human activities are progressively pushing the nitrogen cycle toward a more oxidized state [Vitousek et al., 1997]. The oxidation of reactive nitrogen takes place by nitrification, nitrate fertilizer production, and combustion (equations (1) to (3) in Table 1). All of these oxidation processes cause an uptake of $\mathrm{O}_{2}$ from the atmospheric reservoir, as first suggested by Keeling [1988]. In the opposite case, nitrogenase, a reduction of nitrate by plants to incorporate $\mathrm{N}$ in their tissues, requires electrons which can be supplied by the dissociation of water, contributing a source of $\mathrm{O}_{2}$ to the atmosphere (equation (4) in Table 1 and O'Neill [1993]). Thirdly, the reduction of oxidized nitrogen by denitrification in anoxic environments consumes energy provided by organic material, releasing $\mathrm{CO}_{2}$ to the atmosphere (equation (5) in Table 1 and O'Neill [1993]). Finally, $\mathrm{CO}_{2}$ is 


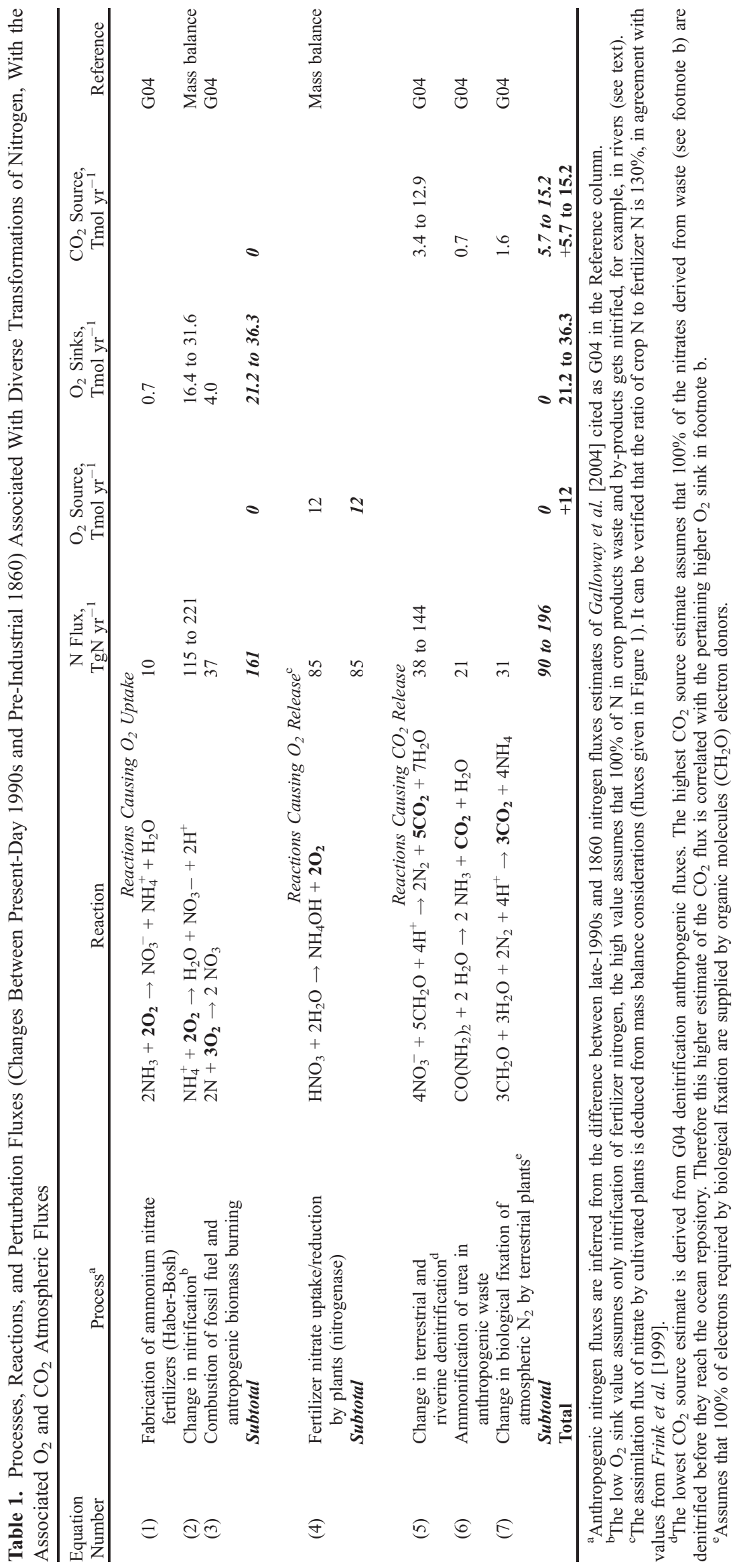


also emitted to the atmosphere during the ammonification of urea (equation (6) in Table 1) and during biological fixation (equation (7) in Table 1). In the following, we show that the sum of the diverse fluxes of anthropogenic $\mathrm{N}$ is a net sink of atmospheric $\mathrm{O}_{2}$. The perturbation of denitrification conversely translates into a source of $\mathrm{CO}_{2}$. Overall, the $\mathrm{CO}_{2}$ source is smaller than the $\mathrm{O}_{2}$ sink. This decreases the $\mathrm{O}_{2}$ to $\mathrm{CO}_{2}$ molar ratio of land biotic fluxes from the 'normal' value of 1.10 , and has an impact on the inferred carbon sinks using oxygen trend measurements.

[6] We assumed that during pre-industrial times, there was a balance between nitrogen oxidation and reduction processes [Galloway et al., 2004], implying that the nitrogen-driven atmospheric $\mathrm{O}_{2}$ and $\mathrm{CO}_{2}$ fluxes were in balance, and the concentrations in equilibrium. In reality, if there was a pre-industrial imbalance in the nitrogen cycle [e.g., Gruber, 2004; Lueker, 2004], it may have been impacting the mean value of the ratio of $\mathrm{O}_{2}$ to $\mathrm{CO}_{2}$ fluxes, but not the trends in atmospheric $\mathrm{O}_{2}$ and $\mathrm{CO}_{2}$ caused by the anthropogenic perturbation of the carbon and oxygen cycles.

[7] The human perturbation of the nitrogen cycle is illustrated in Figure 1. The perturbation fluxes begin by nitrogen inputs from fertilizers to croplands, followed by nitrogenase and incorporation of $\mathrm{N}$ into crop tissues (proteins) and by passage through food webs. In the end, terrestrial and freshwater denitrification fluxes are also perturbed. Other perturbed nitrogen fluxes are associated with human-caused fires and fossil fuel combustion, as well as with an increasing rate of atmospheric $\mathrm{N}$ fixation reflecting legume cultivation. All of these processes transfer nitrogen from the atmospheric $\mathrm{N}_{2}$ reservoir into reactive N pools (see Galloway et al. [2003] for a detailed description). Thus a shift is created to higher oxidation states of reactive nitrogen, principally by increasing the pool of nitrates in soils. Human activities further increase the mobility of nitrates, by modifying the transport of nitrogen in freshwater systems. In particular, the channeling of rivers and the suppression of wetlands would tend to reduce the exposure of nitrate ions to denitrification [see, e.g., Meybeck and Ragu, 1996]. If a large fraction of the additional nitrates produced by human activities are deposited or transported to the deep ocean, they will be sequestered on the order of 2000 years [Brandes and Devol, 2002].

[8] We produced estimates of the removal/addition of atmospheric $\mathrm{O}_{2}$ via various oxidation/reduction channels of reactive nitrogen (Table 1). Most of the nitrogen fluxes are taken from the synthesis of Galloway et al. [2004]. Importantly, we look here only at the perturbation of the $\mathrm{N}$ fluxes, defined as the difference between the late 1990s and 1860 [Galloway et al., 2004, Table 2]. Missing anthropgenic N fluxes to close the budget are inferred by mass balance calculations (from fluxes in Figure 1). The relevant fluxes of $\mathrm{N}$, and their counterpart $\mathrm{O}_{2}$ and $\mathrm{CO}_{2}$ fluxes are estimated below.

\section{Results}

\subsection{Oxygen Sinks From Fertilizer Use and Nitrification}

[9] A removal of atmospheric $\mathrm{O}_{2}$ is associated with the production of industrial fertilizers (equation (1) in Table 1) provided that $\mathrm{N}$ in fertilizers originates from the atmospheric $\mathrm{N}_{2}$ reservoir. Today, the fabrication of $100 \mathrm{TgN} \mathrm{yr}^{-1}$ of industrial nitrogen fertilizers takes place via the Haber-Bosh process, using the atmospheric $\mathrm{N}$ pool [Galloway et al., 2004]. This flux is divided into $10 \mathrm{TgN} \mathrm{yr}^{-1}$ of ammonium nitrate $\left(\mathrm{NH}_{4} \mathrm{NO}_{3}\right)$ and $90 \mathrm{TgN} \mathrm{yr}^{-1}$ of other types of fertilizers containing $\mathrm{NH}_{4}-\mathrm{N}$. The industrial fabrication of ammonium nitrate is a direct sink of atmospheric $\mathrm{O}_{2}$, equalling $0.7 \mathrm{TmolO}_{2} \mathrm{yr}^{-1}$ (Figure 1 and equation (1) in Table 1). Most of the reactive $\mathrm{NH}_{4}-\mathrm{N}$ nitrogen carried by other man-made fertilizers and added to cultivated soils is subject to nitrification (Galloway et al. [2004] and equation (2) in Table 1). The great majority of plants absorb nitrate preferentially to ammonium, because nitrate is more mobile than ammonium [Recous et al., 1992; Cox and Reisenauer, 1973; Crawford and Glass, 1998]. Therefore most of the $\mathrm{NH}_{4}-\mathrm{N}$ nitrogen in fertilizers is oxidized into nitrate by nitrifying bacteria in the soil before it can be fixed by plant roots. Only in acidic soils, the nitrification reaction could be inhibited. In that case, instead of $\mathrm{NO}_{3}^{-}$, plants preferably use $\mathrm{NH}_{4}^{+}$or low-molecular organic nitrogen. A reasonable estimate of the nitrification channel is that $90 \%$ of the total $\mathrm{NH}_{4}-\mathrm{N}$ nitrogen in fertilizers, that is a flux of $81 \mathrm{TgN} \mathrm{yr}^{-1}$, gets nitrified by soil bacteria [Killham, 1994]. This flux must be diminished by losses through soil $\mathrm{NH}_{3}$ emissions (14 $\mathrm{TgN} \mathrm{yr}^{-1}$; Figure 1 corresponding to the emissions terms called 'cro' and 'fer' in Table 2 of Galloway et al. [2004]) and augmented by the input of additional anthropogenic $\mathrm{N}$ from crop residues laid off to the soil. We estimated that this process of incorporation of crop residues to cultivated soils delivers annually $20 \mathrm{TgN} \mathrm{yr}^{-1}$ of reactive nitrogen to plants (estimated using a global crop harvest index of 0.8 and crop biomass C:N ratios given by Goudriaan et al. [2001]). This extra input of nitrogen to the soil is assumed to become mineralized into nitrates in one year. One must also account for the atmospheric deposition of $\mathrm{NH}_{4}-\mathrm{N}$ (29 $\mathrm{TgN} \mathrm{yr}^{-1}$; Figure 1), an input to the soil $\mathrm{NH}_{4}-\mathrm{N}$ pool which occurs very close to emission regions [Warneck, 1988]. An additional flux is due to $\mathrm{N}$ in organic form in byproducts and waste.

[10] We made two extreme estimates of the effect of the anthropogenic nitrification flux on the $\mathrm{O}_{2}$ budget. In the first one, all $\mathrm{N}$ in waste is assumed to get nitrified $\left(106 \mathrm{TgN} \mathrm{yr}^{-1}\right)$ and all the nitrates produced are transported and stored into the ocean. This would increase the total nitrification $\mathrm{O}_{2}$ uptake to an upper value of $31.6 \mathrm{Tmol} \mathrm{O}_{2} \mathrm{yr}^{-1}$ (Figure 1 and Table 1). The second extreme estimate considers that $100 \%$ of $\mathrm{N}$ in waste remains stored in organic form and thus has no impact on atmospheric $\mathrm{O}_{2}$. In that case, the nitrification flux concerns only $\mathrm{N}$ delivered in fertilizers and it is of $115 \mathrm{TgN} \mathrm{yr}^{-1}$ (Table 1), implying an atmospheric $\mathrm{O}_{2}$ uptake lower value of $16.4 \mathrm{Tmol} \mathrm{O}_{2} \mathrm{yr}^{-1}$.

[11] Finally, one can observe that the anthropogenic

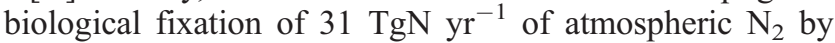
legume cultivars (see Figure 1 and Galloway et al. [2004]) does not involve $\mathrm{O}_{2}$, but emits $\mathrm{CO}_{2}$ (see equation (7) in Table 1 and section 5). The nitrogen biological fixation process is thus neutral with respect to the atmospheric $\mathrm{O}_{2}$ budget. However, the process of biological nitrogen fixation still acts as a positive feedback to the soil nitrification oxygen 
sink by increasing $\mathrm{N}$ in the biomass pool, and subsequently in the flux of crop residues addition (Figure 1).

\subsection{Oxygen Sinks From Combustion Processes}

[12] The high-temperature combustion of fossil fuel in engines produces $\mathrm{NO}_{\mathrm{x}}\left(\mathrm{NO}_{\mathrm{x}}=\mathrm{NO}+\mathrm{NO}_{2}\right)$ and consumes atmospheric $\mathrm{O}_{2}$ (equation (3) in Table 1). The associated flux is $33 \mathrm{TgN} \mathrm{yr}^{-1}$ after Prather et al. [2001] quoted in IPCCTAR, implying an $\mathrm{O}_{2}$ uptake of $3.5 \mathrm{TmolO}_{2} \mathrm{yr}^{-1}$. Additionaly, wildfires emit $\mathrm{NO}_{\mathrm{x}}$ and remove $\mathrm{O}_{2}$ by the same equation (3) in Table 1. Since we are concerned here only by the human perturbation of $\mathrm{N}$ fluxes, the anthropogenic component of biomass burning must be separated from the natural one. Following the recent biomass burning history reconstructed by Mouillot et al. [2006], we estimated that the anthropogenic share represents $60 \%$ of the total biomass burning $\mathrm{N}$ emission. From the total biomass burning $\mathrm{N}$ emissions (that is $\mathrm{NO}_{\mathrm{x}}$ ) reported by Prather et al. [2001] of $7 \mathrm{TgN} \mathrm{yr}^{-1}$, we therefore derived an anthropogenic $\mathrm{NO}_{\mathrm{x}}$ source

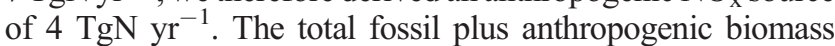
burning source of $\mathrm{N}$ to the atmosphere is of $37 \mathrm{TgN} \mathrm{yr}^{-1}$.

[13] The $\mathrm{NO}_{\mathrm{x}}$ compounds emitted by fossil fuel and anthropognic biomass burning are transformed into nitric acid, and further deposited as nitrates a few days after emissions [Warneck, 1988]. The current $\mathrm{NO}_{\mathrm{x}}$ deposition flux is $24.8 \mathrm{TgN} \mathrm{yr}^{-1}$, while its spatial distribution and the fate of deposited ions remain uncertain [see Lamarque et al., 2005]. We estimated that the $37 \mathrm{TgN} \mathrm{yr}^{-1}$ of $\mathrm{NO}_{\mathrm{X}}$ emissions cause a sink of $4 \mathrm{Tmol} \mathrm{O}_{2} \mathrm{yr}^{-1}$ (Figure 1 and equation (3) in Table 1). This oxygen uptake is likely to be underestimated because it ignores $\mathrm{NO}_{\mathrm{x}}$ emissions produced by the combustion of biofuels and non-road transport, which may account for $2 \%$ of the emissions.

[14] Altogether, the combustion of fossil fuels, the burning of biomass by human activities, the industrial production of ammonium nitrate, and the nitrification of fertilizers $\mathrm{N}$ in soils produce a total sink of 21.2 to $36.3 \mathrm{TmolO}_{2} \mathrm{yr}^{-1}$ (see Table 1). This $\mathrm{O}_{2}$ uptake is equivalent to $3 \%$ of the annual uptake caused by fossil fuel combustion over the period 1993-2003. Thus it remains a small flux.

\subsection{Oxygen Sources From Plant Nitrogen Use}

[15] Once taken up by plant roots, nitrate ions have to be transformed into amino-acids before they can be incorporated into proteins to be used for enzymes and other plant tissues. The nitrate assimilation (= reduction) by the plant can be represented as

$$
\mathrm{HNO}_{3}+8 \mathrm{H}^{+}+8 \mathrm{e}^{-} \rightarrow \mathrm{NH}_{4} \mathrm{OH}+2 \mathrm{H}_{2} \mathrm{O} .
$$

[16] In this process, the oxygen in the nitrate is transferred to water. Electrons needed for the reduction come via the oxidation of $\mathrm{NADPH}_{2}$ to $\mathrm{NADPH}^{+}+\mathrm{H}^{+}$and the $\mathrm{NADPH}^{+}$ has to be recycled (reduced) to $\mathrm{NADPH}_{2}$ in the plant cell again. In plant cells there is often a surplus of electrons. Depending on where the nitrate assimilation takes place, the electrons for the reduction of $\mathrm{NADPH}^{+}$can come (1) from mitochondrial dissimilation of carbohydrates, resulting in a release of $\mathrm{CO}_{2}$, (2) from fermentation processes that do not release any gases, or (3) directly from the photooxidation of
$\mathrm{H}_{2} \mathrm{O}\left(\mathrm{H}_{2} \mathrm{O} \rightarrow 2 \mathrm{H}^{+}+2 \mathrm{e}^{-}+1 / 2 \mathrm{O}_{2}\right)$. Only this third source of electrons causes a release of $\mathrm{O}_{2}$ to the atmosphere. In the extreme case where all the electrons could come from this channel, one can write as the overall equation for nitrate assimilation as

$$
\mathrm{HNO}_{3}+2 \mathrm{H}_{2} \mathrm{O} \rightarrow \mathrm{NH}_{4} \mathrm{OH}+2 \mathrm{O}_{2} .
$$

[17] This corresponds to equation (4) in Table 1. Hence, per mole of $\mathrm{NO}_{3}^{-}$reduced, two moles of $\mathrm{O}_{2}$ are net-released to the atmosphere. The amount of nitrate incorporated into plant proteins is inferred from mass balance calculations (from the fluxes in Figure 1). We estimate that $85 \mathrm{TgN} \mathrm{yr}^{-1}$ are reduced by nitrogenase, which causes a source of $12 \mathrm{Tmol} \mathrm{O}_{2} \mathrm{yr}^{-1}$. This source offsets 33 to $57 \%$ of the nitrification and combustion $\mathrm{O}_{2}$ uptake. It is likely to be an overestimate however, because we have assumed that all the electrons come from cell water, the third possible mechanism described above.

\section{Impact on Global Carbon Sinks Estimates}

[18] The existence of a sink of atmospheric $\mathrm{O}_{2}$ from the global nitrogen cycle becoming more oxidised has an impact on global carbon sinks as determined from atmospheric $\mathrm{O}_{2} / \mathrm{N}_{2}$ and $\mathrm{CO}_{2}$ trends [Bender et al., 2005; Keeling and Shertz, 1992, 2005; Manning and Keeling, 2006]. The nitrogen reactions above act to decrease the oceanic carbon sink and increase the land biotic carbon sink by an equal amount. We recalculated these carbon sinks on the basis of recent atmospheric observations over 1993-2003 [Manning and Keeling, 2006]. We also employed the same calculation methodologies as given by Manning and Keeling [2006]. The results are reported in Table 2 and shown graphically in Figure 2.

[19] We find that including the nitrification and combustion reactions of $\mathrm{O}_{2}$ uptake summed in Table 1 (equations (1), (2) and (3)) results in a land biotic sink of $0.74 \pm 0.78 \mathrm{PgC} \mathrm{yr}^{-1}$ and an oceanic sink of $2.01 \pm 0.66 \mathrm{PgC} \mathrm{yr}^{-1}$ (Table 2,

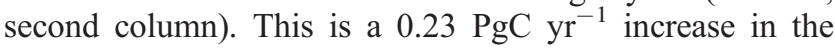
land biotic sink, and an equivalent decrease in the oceanic sink, compared to the Manning and Keeling [2006] 19932003 estimate. For the land biotic sink, this represents a relatively large $45 \%$ increase. These calculations are also illustrated in Figure 2a in vector diagram format, after Keeling et al. [1996]. The nitrogen correction is the short, vertical, green vector. (The figure caption provides details of all vectors shown). To compare these results with the results of Manning and Keeling [2006], one can imagine extending the horizontal vector (oceanic sink) until it intersects the typical land biotic sink vector (with $\mathrm{O}_{2} / \mathrm{CO}_{2}$ slope of 1.1). This intersection point illustrates the extension of the oceanic sink vector and shortening of the land biotic sink vector, in other words, the larger oceanic sink and smaller land biotic sink presented by Manning and Keeling [2006].

[20] In the third column of Table 2, we have added the less certain estimate from nitrate reduction (Table 1, equation (4)), which decreases the carbon sinks correction to $0.10 \mathrm{PgC} \mathrm{yr}^{-1}$. In these calculations we have used our lower estimate for nitrifcation fluxes (Table 1), because of a $\mathrm{CO}_{2}$ complicity 
Table 2. The 1993-2003 Global Carbon Budget and Partitioning of Carbon Sinks Between the Land Biosphere and Oceans Inferred From Atmospheric $\mathrm{O}_{2} / \mathrm{N}_{2}$ and $\mathrm{CO}_{2}$ Measurements, Without and With the Anthropogenic Nitrogen Corrections as Given in Table $1^{\mathrm{a}}$

\begin{tabular}{|c|c|c|c|c|c|}
\hline All Data in $\mathrm{Pg} \mathrm{C} \mathrm{yr}^{-1}$ & $\begin{array}{l}\text { Manning and } \\
\text { Keeling [2006] }\end{array}$ & $\begin{array}{l}\text { Correction 1: } \\
\text { Corrected for } \\
\mathrm{O}_{2} \text { Uptake From } \\
\text { Nitrification and } \\
\text { Combustion }\end{array}$ & $\begin{array}{l}\text { Correction 2: } \\
\text { Corrected for } \\
\mathrm{O}_{2} \text { Release From } \\
\text { Nitrate Reduction }+ \\
\text { Correction 1 }\end{array}$ & $\begin{array}{l}\text { Correction 3a: } \\
\text { Corrected for } \\
\mathrm{CO}_{2} \text { Release }+ \\
\text { Correction } 1+ \\
\text { Correction 2 - } \\
\text { Low Estimate }\end{array}$ & $\begin{array}{l}\text { Correction 3b: } \\
\text { Corrected for } \\
\mathrm{CO}_{2} \text { Release }+ \\
\text { Correction } 1+ \\
\text { Correction } 2- \\
\text { High Estimate }\end{array}$ \\
\hline Land biotic uptake & $0.51 \pm 0.74$ & $0.74 \pm 0.78$ & $0.61 \pm 0.75$ & $0.54 \pm 0.76$ & $0.59 \pm 0.83$ \\
\hline Oceanic uptake & $2.24 \pm 0.61$ & $2.01 \pm 0.66$ & $2.14 \pm 0.62$ & $2.21 \pm 0.63$ & $2.16 \pm 0.70$ \\
\hline Land biotic $\mathrm{O}_{2} \cdot \mathrm{CO}_{2}$ ratio $^{\mathrm{b}}$ & 1.1 & 0.76 & 0.92 & 1.04 & 0.95 \\
\hline
\end{tabular}

${ }^{a}$ Correction 1 uses the low $\mathrm{O}_{2}$ sink estimate of $21.2 \mathrm{Tmol} \mathrm{O}_{2} \mathrm{yr}^{-1}$; correction 2 uses this $\mathrm{O}_{2}$ sink estimate and the $\mathrm{O}_{2}$ source of $12 \mathrm{Tmol}_{2} \mathrm{yr}^{-1}$; correction 3a uses the low $\mathrm{O}_{2}$ sink estimate of $21.2 \mathrm{Tmol} \mathrm{O}_{2} \mathrm{yr}^{-1}$, the $\mathrm{O}_{2}$ source of $12 \mathrm{Tmol} \mathrm{O}_{2} \mathrm{yr}^{-1}$, and the low $\mathrm{CO}_{2}$ source estimate of $5.7 \mathrm{Tmol} \mathrm{CO}_{2}$ $\mathrm{yr}^{-1}$; and correction $3 \mathrm{~b}$ uses the high $\mathrm{O}_{2}$ sink estimate of $36.3 \mathrm{Tmol} \mathrm{O}_{2} \mathrm{yr}^{-1}$, the $\mathrm{O}_{2}$ source of $12 \mathrm{Tmol} \mathrm{O}_{2} \mathrm{yr}^{-1}$, and the high $\mathrm{CO}_{2}$ source estimate of $15.2 \mathrm{Tmol} \mathrm{CO}_{2} \mathrm{yr}^{-1}$. Uncertainties have been estimated by propagation of errors, assuming $100 \%$ uncertainty on both the nitrogen-related $\mathrm{O}_{2}$ fluxes and the nitrogen-related $\mathrm{CO}_{2}$ fluxes reported in Table 1. As in work by Manning and Keeling [2006], all calculations use global fossil fuel emissions of $6.48 \pm$

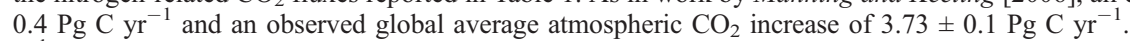

${ }^{b}$ Units are moles of $\mathrm{O}_{2}$ produced per mole of $\mathrm{CO}_{2}$ consumed.

explained in section 5. Because of the uncertainty in the literature for nitrogen fluxes, we conservatively assumed $100 \%$ uncertainties on all nitrogen fluxes used in our global sink calculations. These uncertainties were propagated to the oceanic and land biotic sink estimates given in Table 2 . For other parameters, we used the same uncertainties given by Manning and Keeling [2006].

\section{Additional Effects and Caveats}

[21] A key question is whether the fluxes of $\mathrm{O}_{2}$ associated with reactive nitrogen reactions in Table 1 are accompanied by any fluxes of $\mathrm{CO}_{2}$. If this is the case, the $\mathrm{O}_{2}: \mathrm{CO}_{2}$ ratio of the fluxes must then be examined. For photosynthesis, a global average ratio of 1.10 moles of $\mathrm{O}_{2}$ produced per mole of $\mathrm{CO}_{2}$ consumed is typically used in global carbon budgeting calculations from atmospheric $\mathrm{O}_{2}$ measurements [Manning and Keeling, 2006; Severinghaus, 1995]. However, this value has not been well-defined, and even its uncertainty $( \pm 0.05)$ is little more than a guess [Severinghaus, 1995]. If there were one or more sources of $\mathrm{CO}_{2}$ caused by nitrogen transformations and associated with the sink of $\mathrm{O}_{2}$ caused by nitrification, they also must be taken into account in correcting for carbon sinks. The existence of $\mathrm{CO}_{2}$ sources and $\mathrm{O}_{2}$ sinks caused by nitrogen fluxes will also change the $\mathrm{O}_{2}: \mathrm{CO}_{2}$ molar ratio of global land biotic fluxes from the expected value of 1.1 Therefore we searched the scientific litterature to investigate the fate of oxidized nitrogen produced by human activities, looking for reactions susceptible to cause $\mathrm{CO}_{2}$ fluxes to the atmosphere.

\subsection{Denitrification and $\mathrm{CO}_{2}$ Emissions}

[22] Denitrification emits $\mathrm{CO}_{2}$ to the atmosphere from the reaction of nitrate or nitrite ions with a substrate of decaying organic matter (equation (5) in Table 1). The very mobile $\mathrm{NO}_{3}^{-}$and $\mathrm{NO}_{2}^{-}$ions produced by fertilizer additions to croplands pass through several filters during their transport from land to ocean. In freshwater systems, they can be denitrified in anoxic groundwaters, in wetlands, foodplains or estuaries [Galloway et al., 2004]. First, the flux of soil nitrates leached from cultivated soils contributes to anthropogenic denitrification. Leaching was estimated to represent up to $40 \%$ of the total fertilizer input globally. There is a large uncertainty in this estimate. We assumed (very)

Figure 2. Vector diagram showing oceanic and land biotic carbon sinks derived from atmospheric observations of $\mathrm{O}_{2} / \mathrm{N}_{2}$ and $\mathrm{CO}_{2}$ over the period 1993-2003. (a) Scenario 1 and (b) scenario 3 b (as given in Table 2). Solid circles are shown every 6 months and are annual mean $\mathrm{O}_{2} / \mathrm{N}_{2}$ ratio and $\mathrm{CO}_{2}$ concentration measurements averaged from three stations in the Scripps Institution of Oceanography flask sampling network, namely Alert Canada, La Jolla U.S.A., and Cape Grim Tasmania. A solid line vector is drawn from the first annual average in January 1993 to the last in January 2003. The expected change in atmospheric $\mathrm{O}_{2} / \mathrm{N}_{2}$ ratio and $\mathrm{CO}_{2}$ concentration from fossil fuel combustion, if no other processes were involved, is shown by the long, labeled vector (with a slope of 1.40 moles of $\mathrm{O}_{2}$ consumed per mole of $\mathrm{CO}_{2}$ produced). From the fossil fuel endpoint, the short vertical vector indicates oceanic $\mathrm{O}_{2}$ outgassing as discussed in the text. From this vertical vector, the horizontal vector indicates the calculated oceanic carbon sink. From the end of the oceanic carbon sink vector, the short vector (vertical in Figure 2a, diagonal in Figure 2b; green in color versions) shows the nitrogen corrections. From this vector, the "typical" land biotic carbon sink vector is shown, with slope 1.10, returning to the atmospheric observations average point for January 2003. The vector sum of the nitrogen correction vectors and the typical land biotic sink vector is also shown (connecting the January 2003 observation point with the oceanic sink vector; red in color versions). This vector represents the net land biotic carbon sink taking into account anthropogenic nitrogen fluxes as discussed, and has slope 0.76 moles of $\mathrm{O}_{2}$ produced per mole of $\mathrm{CO}_{2}$ consumed in Figure $2 \mathrm{a}$ and 0.95 in Figure $2 \mathrm{~b}$. We verified that denitrification and fertilizer production, respectively a source and a sink of atmospheric $\mathrm{N}_{2}$, induce negligible changes in the large atmospheric $\mathrm{N}_{2}$ reservoir, and therefore do not impact the $\mathrm{O}_{2} / \mathrm{N}_{2}$ ratio. 
conservatively that $90 \%$ of the leached fertilizer nitrates $(38$ $\mathrm{TgN} \mathrm{yr}^{-1}$ deduced from mass balance in Figure 1) are presently denitrified before reaching the ocean [Galloway et al., 2004]. This assumption leads to a lower end estimate of

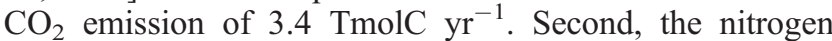
incorporated into crop biomass and then harvested, passes through food webs, just as carbohydrates do (Figure 1). Animal and human metabolism produce excretions and waste, which return reactive nitrogen to the environment. An additional denitrification flux could come from the transformation of $\mathrm{N}$ in excetions and organic waste (Figure 1). There are large uncertainties on the fate of $\mathrm{N}$ in waste. If we follow the extreme case of section 3.1 that $100 \%$ of waste $\mathrm{N}$ is nitrified and further assume that it is all denitrified, we would obtain a denitrification flux of 106

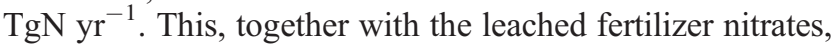
would give an upper end estimate of $\mathrm{CO}_{2}$ emissions of 12.9 TmolC $\mathrm{yr}^{-1}$ (Table 1).

\subsection{Other Nitrogen Fluxes Causing $\mathrm{CO}_{2}$ Emissions}

[23] Excretion products are mineralized into nitrate, urea or ammonia, the latter via the ammonification reaction (equation (6) in Table 1). Ammonification of decaying organic nitrogen causes no loss of $\mathrm{CO}_{2}$. However, ammo-
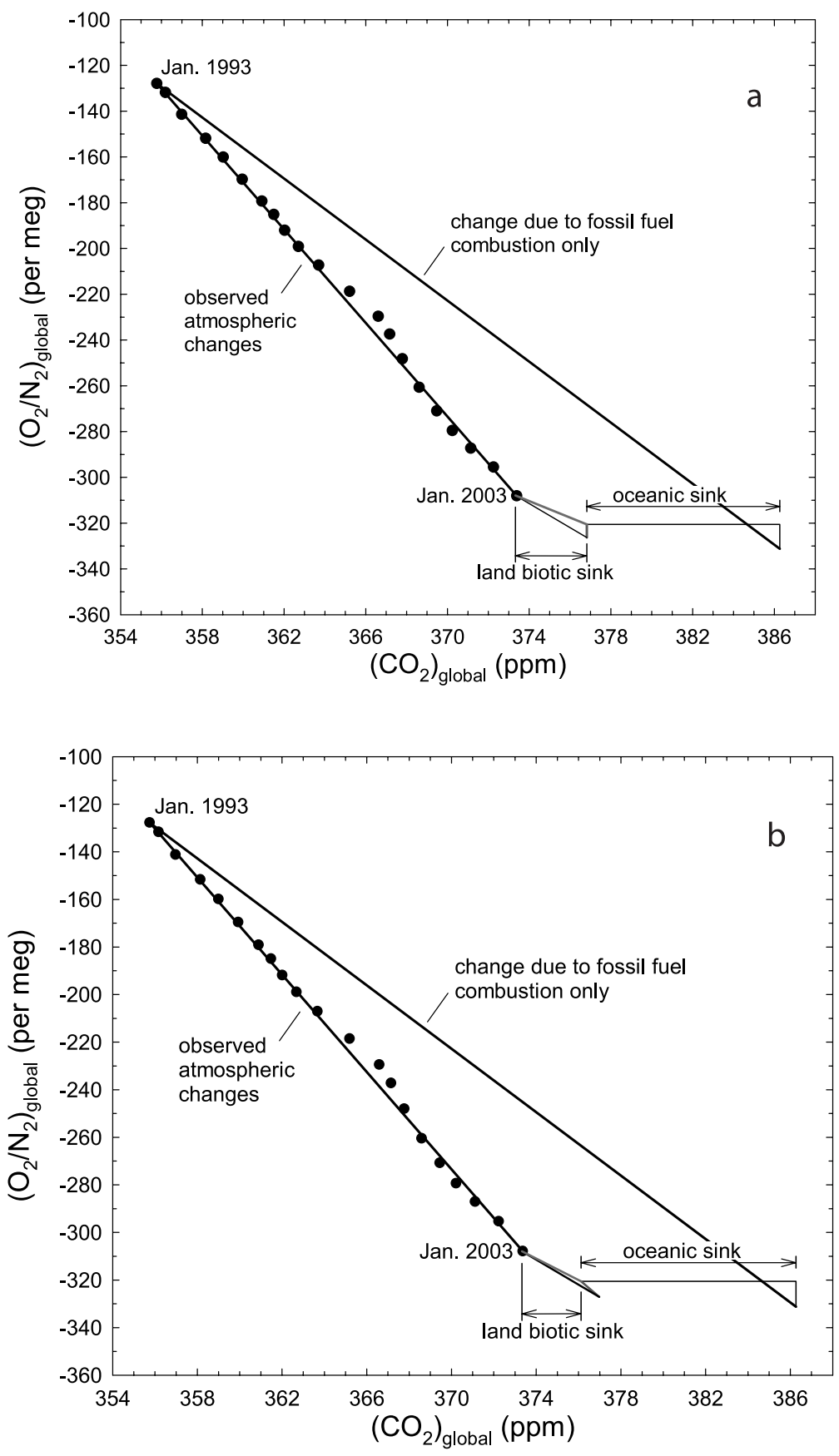

Figure 2 
nification of urea (see Figure 1) causes a source of $\mathrm{CO}_{2}$ of 0.7 TmolC $\mathrm{yr}^{-1}$. Note that the $\mathrm{NH}_{4}-\mathrm{N}$ vented to the atmosphere during ammonification gets deposited to the surface after a few days. Some of this reactive nitrogen may just be nitrified and provoke a supplementary fixation of atmospheric $\mathrm{O}_{2}$ (Figure 1). Finally, the biological fixation of $\mathrm{N}$ requires electrons that must be supplied by carbohydrates (equation (7) in Table 1). Thus the small (and uncertain) increase in biological fixation since preindustrial times [Galloway et al., 2004] induces a source of

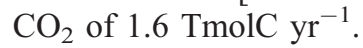

\subsection{Denitrification and Nitrous Oxide Emissions}

[24] Denitrification emits mostly $\mathrm{N}_{2}(96 \%)$ to the atmosphere and a very small flux of $\mathrm{N}_{2} \mathrm{O}(4 \%)$. Thus the atmospheric pool of $\mathrm{N}_{2} \mathrm{O}$ is currently increasing owing to fertilizer denitrification in agricultural soils. Such an excess of atmospheric $\mathrm{N}_{2} \mathrm{O}$ will sequester atmospheric oxygen, owing to the long atmospheric lifetime of $\mathrm{N}_{2} \mathrm{O}$ with respect to its photolysis in the stratosphere $(110-170$ years in the work by Mahlman et al. [1986]). We estimated the net anthropogenic emissions of $\mathrm{N}_{2} \mathrm{O}$ to be $2.1 \mathrm{TgN} \mathrm{yr}^{-1}$ after the Table 1 of Galloway et al. [2004]. This flux causes a tiny sink of $\mathrm{O}_{2}$ of $0.1 \mathrm{Tmol} \mathrm{O}_{2} \mathrm{yr}^{-1}$, a negligible flux in the context of this analysis, and thus not considered further.

\subsection{Ocean Nitrogen Cycle}

[25] Another source of uncertainty may arise from the ocean nitrogen budget. Recent studies have challenged its stability with respect to $\mathrm{N}$ sinks (including biological $\mathrm{N}_{2}$ fixation) estimated to be $265-294 \mathrm{TgN} \mathrm{yr}^{-1}$ and $\mathrm{N}$ sources (mainly water column and benthic denitrification) estimated to be 275-482 $\mathrm{TgN} \mathrm{yr}^{-1}$ (see Gruber [2004] for a review). This imbalance, if asserted, may lead to a net $\mathrm{CO}_{2}$ outgassing from the ocean [Gruber, 2004] that may impact the atmospheric budget without any counterpart on the $\mathrm{O}_{2}$ budget. However, uncertainties of the ocean source and sink terms here are so large that it is therefore unclear whether such an imbalance exists today. Thus we have decided to leave those potential fluxes apart.

\subsection{Summary Effects of $\mathrm{N}$-Related $\mathrm{CO}_{2}$ Emissions on Carbon Sinks}

[26] We estimated net $\mathrm{CO}_{2}$ emissions from anthropogenic changes in the nitrogen cycle since preindustrial times in the range from 5.7 to $15.2 \mathrm{TmolC}^{-1}$ (Table 1). This total flux was estimated very conservatively with respect to the possible impact on the oceanic and land biotic carbon sinks. In other words, a less conservative estimate would result in a larger sinks correction. Note that our high estimate of the $\mathrm{CO}_{2}$ emissions from waste denitrification is correlated with the high estimate of the $\mathrm{O}_{2}$ sink from waste nitrification (see caption of Table 1). If $\mathrm{N}$ in waste is not nitrified, it cannot be later denitrified. Thus in Table 2, the fourth column (scenario 3a), we provide a low estimate of the N-related correction to the carbon sinks given both a lower $\mathrm{O}_{2}$ sink and a lower $\mathrm{CO}_{2}$ source, and in the fifth column (scenario $3 \mathrm{~b}$ ) we provide a high estimate given both a higher $\mathrm{O}_{2}$ sink and a higher $\mathrm{CO}_{2}$ source. In both scenarios, the $\mathrm{CO}_{2}$ source is less than the $\mathrm{O}_{2}$ uptake, and the $\mathrm{O}_{2}: \mathrm{CO}_{2}$ molar ratio for these nitrification/denitrification fluxes is 1.6 , compared to the 'normal' terrestrial ratio of 1.1 for carbon reduction (photosynthesis) and oxidation (respiration) fluxes. The corresponding corrections to the 1993-2003 global oceanic and land biotic carbon sinks taking into account all of these processes, and using the high estimates above (which are nevertheless conservative), is a $0.08 \mathrm{PgC} \mathrm{yr}^{-1}$ increase in the land biotic sink, and an equivalent decrease in the oceanic sink (see Table 2, fifth column). Figure $2 b$ illustrates scenario $3 \mathrm{~b}$ in vector format, with the green vector showing the nitrogen correction with a slope $\left(\mathrm{O}_{2} / \mathrm{CO}_{2}\right.$ molar ratio) of 1.6 .

[27] It is worth noting that our definition of the land biotic carbon sink is the net effect from all terrestrial processes. Thus while adding nitrification processes result in an increase in the inferred carbon sink, denitification and biological fixation have a counteracting effect, diminishing the overall influence from anthropogenic nitrogen changes. This net terrestrial effect is illustrated by the red vectors in Figures $2 \mathrm{a}$ and $2 \mathrm{~b}$, which have slopes $\left(\mathrm{O}_{2} / \mathrm{CO}_{2}\right.$ molar ratios) of 0.76 and 0.95 respectively (see also Table 2 ).

\section{Discussion}

[28] Incorporating anthropogenic changes in the nitrogen cycle in the global $\mathrm{O}_{2}$ budget has the effect of decreasing the moles of $\mathrm{O}_{2}$ produced per mole of $\mathrm{CO}_{2}$ consumed (or vice versa) in terrestrial fluxes. We calculate that the land biotic $\mathrm{O}_{2}: \mathrm{CO}_{2}$ molar ratio typically used in global carbon budgeting calculations effectively must be changed from 1.10 to a range between 0.76 and 1.04 , depending on which of the 4 scenarios summarized in Table 2 is used. It is important to realize that our corrections to the oceanic and land biotic sinks (Table 2) rest on the assumption that, globally, nitrification exceeds denitrification. We estimated indeed that anthropogenic nitrification is up to 3 times larger than its denitrification counterpart, on the basis of the nitrogen budgets established by Galloway et al. [2004] for 1860 and the early 1990s (their Table 1). Yet it is fair to say that this estimate is uncertain. In particular, changes in denitrification remain very poorly understood. For instance, the chanelling of rivers (Mississipi, Rhine) and the suppression of natural wetlands [Meybeck and Ragu, 1996] could decrease freshwater denitrification. On the other hand, the establishment of dams and the cultivation of rice could have increased regional denitrification [Vitousek et al., 1997]. It is certain that the delivery of nitrate to rivers has dramatically increased in response to agricultural use of fertilizers. It is also widely observed that this has resulted in a massive input of new nitrate to the coastal seas [e.g., Green et al., 2004], causing eutrophication and hypoxia. A particularly striking example is the gulf of Mexico, off the Mississipi Delta (see for instance http://oceanservice.noaa.gov/products/pubs hypox.html). The consequences of such changes in nitrogen input by rivers to the coastal seas for atmospheric $\mathrm{O}_{2}$ fluxes are not well understood. On the one hand, hypoxia could stimulate denitrification and enhance $\mathrm{CO}_{2}$ emissions in the coastal zone. On the other hand, the subsurface oxygen minimum caused by eutrophication could be advected from the coastal 
sea to the open ocean by seasonal water mass exchanges (e.g., the shelf pumping mechanism observed for carbon in the North Sea by Thomas et al. [2005]).

\section{Conclusions}

[29] We have shown that the human perturbation of the global $\mathrm{N}$ cycle results in nitrogen-related oxidation pathways dominating over reduction pathways, with more reactive nitrogen being cycled through the land biota. This oxidative imbalance creates a net uptake of atmospheric $\mathrm{O}_{2}$ and a smaller source of atmospheric $\mathrm{CO}_{2}$. These fluxes are part of the terrestrial carbon and oxygen cycles, but have not been accounted for in previous studies. When accounting for these fluxes, the value of the land biotic $\mathrm{O}_{2}: \mathrm{CO}_{2}$ ratio used in global carbon budgeting must be changed. Using estimates of (anthropogenic) nitrogen-related fluxes from the scientific literature, we calculate that the land biotic $\mathrm{O}_{2}: \mathrm{CO}_{2}$ molar ratio used in global carbon budgeting calculations should be decreased from the typically used value of 1.10 to between 0.76 and 1.04 , depending on different possible anthropogenic nitrogen flux scenarios presented here. Using the fluxes from the scenario which we can report with least uncertainty (scenario 1 in Table 2), we calculate a modified land biotic ratio of 0.76 . This results in changes to the global carbon sinks as recently inferred from atmospheric $\mathrm{O}_{2}$ trends over the period 1993-2003, increasing the land biotic sink by $0.23 \mathrm{PgC} \mathrm{yr}^{-1}$ (a $45 \%$ correction) to $0.74 \pm 0.78 \mathrm{PgC} \mathrm{yr}^{-1}$, and decreasing the oceanic sink by the same amount to $2.01 \pm 0.66{\mathrm{PgC} \mathrm{yr}^{-1}}^{-1}$. There are large uncertainties associated with the magnitude of each nitrogenrelated $\mathrm{O}_{2}$ and $\mathrm{CO}_{2}$ flux, primarily owing to insufficient knowledge of the fate of reactive nitrogen in ecosystems and freshwater systems. Assuming errors of $100 \%$ on each flux yields a range of uncertainties on global carbon fluxes of up to $\pm 0.09{\mathrm{PgC} \mathrm{yr}^{-1}}^{-1}$ greater than when nitrogen fluxes are not considered, as seen in the different columns in Table 2. However, we have been conservative on the side of minimizing the $\mathrm{O}_{2}$ uptake from, for example, fossil fuel burning, plant reduction of nitrate from cell water, and $\mathrm{CO}_{2}$ emissions from denitrification. Therefore our final corrections to the global oceanic and land biotic carbon sinks are also on the conservative side.

[30] In the future, rising fertilizer production and use is anticipated, which will further increase nitrification. In addition, river management and shrinking wetland areas will act to decrease denitrification. Therefore one may anticipate that the anthropogenic nitrogen fluxes will likely continue to consume atmospheric oxygen at even larger rates than today.

[31] Acknowledgment. We thank Ralph Keeling, who kindly provided a copy of his Ph.D. dissertation, where some of the $\mathrm{O}_{2}$ fluxes decoupled from those of $\mathrm{CO}_{2}$ were discussed.

\section{References}

Bender, M., D. T. Ho, M. B. Hendricks, R. Mika, M. O. Battle, P. P. Tans, T. J. Conway, B. Sturtevant, and N. Cassar (2005), Atmospheric $\mathrm{O}_{2} / \mathrm{N}_{2}$ changes, 1993-2002: Implications for the partitioning of fossil fuel $\mathrm{CO}_{2}$ sequestration, Global Biogeochem. Cycles, 19, GB4017, doi:10.1029 2004GB002410.
Bopp, L., C. Le Quéré, M. Heimann, A. C. Manning, and P. Monfray (2002), Climate-induced oceanic oxygen fluxes: Implications for the contemporary carbon budget, Global Biogeochem. Cycles, 16(2), 1022, doi:10.1029/2001GB001445.

Brandes, J. A., and A. H. Devol (2002), A global marine-fixed nitrogen isotopic budget: Implications for Holocene nitrogen cycling, Global Biogeochem. Cycles, 16(4), 1120, doi:10.1029/2001GB001856.

Cox, W. J., and H. M. Reisenauer (1973), Growth and ion uptake by wheat supplied nitrogen as nitrate or ammonium, or both, Plant Soil, $38,363-380$.

Crawford, N. M., and A. D. M. Glass (1998), Molecular and physiological aspects of nitrate uptake by plants, Trends Plant Sci., 3(10), 389-392.

Frink, C. R., P. E. Waggoner, and J. H. Ausubel (1999), Nitrogen fertilizer: Retrospect and prospect, Proc. Natl. Acad. Sci. U. S. A., 96, 1175-1180.

Galloway, J. N., J. D. Aber, J. W. Erisman, S. P. Seitzinger, R. W. Howarth, E. B. Cowling, and B. J. Cosby (2003), The nitrogen cascade, Bioscience, $53,341-356$

Galloway, J. N., et al. (2004), Nitrogen cycles: Past, present, and future, Biogeochemistry, 70, 153-226.

Goudriaan, J., J. J. R. Groot, and P. W. J. Uithol (2001), Productivity of agro-ecosystems, in Terrestrial Global Productivity, edited by J. Roy et al., pp. 301-314, Academic, San Diego, Calif.

Green, P. A., C. J. Vörösmarty, M. Meybeck, J. N. Galloway, B. J. Peterson, and E. W. Boyer (2004), Pre-industrial and contemporary fluxes of nitrogen through rivers: A global assessment based on typology, Biogeochemistry, 68, 71-105.

Gruber, N. (2004), The dynamics of the marine nitrogen cycle and its influence on atmospheric $\mathrm{CO}_{2}$ variations, in The Ocean Carbon Cycle and Climate: Proceedings of the NATO ASI on Ocean Carbon Cycle and Climate, Ankara, Turkey, 5-16 August 2002, edited by M. Follows and T. Oguz, pp. 97-148, Kluwer Acad., Dordrecht, Netherlands.

Keeling, R. F. (1988), Development of an interferometric oxygen analyzer for precise measurement of the atmospheric $\mathrm{O}_{2}$ mole fraction, Ph.D. thesis, 178 pp., Harvard Univ., Cambridge, Mass.

Keeling, R. F., and H. E. Garcia (2002), The change in oceanic O-2 inventory associated with recent global warming, Proc. Natl. Acad. Sci. U. S. A., 99, 7848-7853.

Keeling, R. F., and S. R. Shertz (1992), Seasonal and interannual variations in atmospheric oxygen and implications for the global carbon cycle, Nature, 358, 723-727.

Keeling, R., S. C. Piper, and M. Heimann (1996), Global and hemispheric $\mathrm{CO}_{2}$ sinks deduced from changes in atmospheric $\mathrm{O}_{2}$ concentration, Nature, $381,218-221$.

Killham, K. (1994), Soil Ecology, Cambridge Univ. Press, Cambridge, U.K

Lamarque, J. F., et al. (2005), Assessing future nitrogen deposition and carbon cycle feedback using a multimodel approach: Analysis of nitrogen deposition, J. Geophys. Res., 110, D19303, doi:10.1029/2005JD005825.

Levitus, S., J. I. Antonov, T. P. Boyer, and C. Stephens (2000), Warming of the world ocean, Science, 287, 2225-2229.

Lueker, T. J. (2004), Coastal upwelling fluxes of $\mathrm{O}_{2}, \mathrm{~N}_{2} \mathrm{O}$ and $\mathrm{CO}_{2}$ assessed from continuous atmospheric observations at Trinidad, California, Biogeosciences, 1, 101-111.

Mahlman, J., H. Levy, and W. Moxim (1986), Three-dimensionnal simulations of stratospheric $\mathrm{N}_{2} \mathrm{O}$ : Predictions for other trace constituents, J. Geophys. Res., 91, 2687-2707.

Manning, A. C. (2001), Temporal variability of atmospheric oxygen from both continuous measurements and a flask sampling network: Tools for studying the global carbon cycle, Ph.D. thesis, 202 pp., Univ. of Calif., San Diego, La Jolla.

Manning, A. C., and R. F. Keeling (2006), Global oceanic and land biotic carbon sinks from the Scripps atmospheric oxygen flask sampling network, Tellus, Ser. B, 58, 95-116.

Marca, A. D. (2004), A new instrument for precise atmospheric $\mathrm{O}_{2}$ measurements, and its use to study uptake and release of $\mathrm{O}_{2}$ and $\mathrm{CO}_{2}$ by terrestrial vegetation, Ph.D. thesis, 199 pp., Univ. of East Anglia, Norwich, U.K.

Marland, G., T. A. Boden, and R. J. Andres (2003), Global, regional, and national fossil fuel $\mathrm{CO}_{2}$ emissions, in Trends: A Compendium of Data on Global Change, Carbon Dioxide Inf. Anal. Cent., Oak Ridge Natl. Lab., U.S. Dep. of Energy, Oak Ridge, Tenn.

Meybeck, M., and A. Ragu (1996), River discharges to the oceans: An assessment of suspended solids, major ions, and nutrients, report, 250 pp., U.N. Environ. Programme, Nairobi.

Mouillot, F., A. Narasimha, Y. Balkanski, J. F. Lamarque, and C. B. Field (2006), Global carbon emissions from biomass burning in the 20th century, Geophys. Res. Lett., 33, L01801, doi:10.1029/2005GL024707.

O’Neill, P. (1993), Environmental Chemistry, Nelson Thornes, London. 
Plattner, G. K., F. Joos, and T. F. Stocker (2002), Revision of the global carbon budget due to changing air-sea oxygen fluxes, Global Biogeochem. Cycles, 16(4), 1096, doi:10.1029/2001GB001746.

Prather, M., D. Ehhalt, F. Dentener, R. G. Derwent, and E. Dlugokencky (2001), Atmospheric chemistry and greenhouse gases, in Climate Change 2001: The Scientific Basis-Contribution of Working Group I to the Third Assessment Report of the Intergovernmental Panel on Climate Change (IPCC), edited by J. T. Houghton et al., pp. 239-287, Cambridge Univ. Press, Cambridge, U.K.

Prentice, I. C., et al. (2001), The carbon cycle and atmospheric carbon dioxide, in Climate Change 2001: The Scientific Basis-Contribution of Working Group I to the Third Assessment Report of the Intergovernmental Panel on Climate Change (IPCC), edited by J. T. Houghton et al., pp. 183-237, Cambridge Univ. Press, Cambridge, U.K.

Randerson, J. T., C. A. Masiello, C. J. Still, T. Rahn, H. Poorter, and C. B. Field (2006), Is carbon within the global terrestrial biosphere becoming more oxidized? Implications for trends in atmospheric $\mathrm{O}_{2}$, Global Change Biol., 12, 260-271.

Recous, S., J. M. Machet, and B. Mary (1992), The partitionning of fertilizer-N between soil and crop: Comparison of ammonium and nitrate applications, Plant Soil, 144, 101-111.

Seibt, U., W. A. Brand, M. Heimann, J. Lloyd, J. P. Severinghaus, and L. Wingate (2004), Observations of $\mathrm{O}_{2}: \mathrm{CO}_{2}$ exchange ratios during ecosystem gas exchange, Global Biogeochem. Cycles, 18, GB4024, doi:10.1029/2004GB002242.
Severinghaus, J. P. (1995), Studies of the terrestrial $\mathrm{O}_{2}$ and carbon cycles in sand dune gases and in Biosphere 2, Ph.D. thesis, 148 pp., Columbia Univ., New York.

Stephens, B. B., P. S. Bakwin, P. P. Tans, R. M. Teclaw, and D. D. Baumann (2007), Application of a differential fuel-cell analyzer for measuring atmospheric oxygen variations, J. Atmos. Oceanic Technol., 24(1), 8294.

Thomas, H., Y. Bozec, H. J. W. De Baar, K. Elkalay, M. Frankignoulle, and L.-S. Schiettecatte (2005), The carbon budget of the North Sea, Biogeosciences, 2, 87-96.

Vitousek, P. M., J. D. Aber, R. W. Howarth, G. E. Likens, P. A. Matson, D. W. Schindler, W. H. Schlesinger, and D. G. Tilman (1997), Human alteration of the global nitrogen cycle: Sources and consequences, Ecol. Appl., 7, 737-750.

Warneck, P. (1988), Chemistry of the Natural Atmosphere, Academic, San Diego, Calif.

L. Bopp, P. Ciais, and S. Zaehle, Laboratoire des Sciences du Climat et de 1'Environnement, Orme des Merisiers, F-91191 Gif-sur-Yvette, France. (philippe.ciais@cea.fr)

A. C. Manning, School of Environmental Sciences, University of East Anglia, Norwich NR4 7TJ, UK.

M. Reichstein, Max-Planck Institute for Biogeochemistry, D-07745 Jena, Germany. 